\title{
Status and management of non-native plant invasion in three of the largest national parks in the United States
}

\author{
Scott R. Abella', Nicholas A. Fisichelli², Sarah M. Schmid ${ }^{3}$, \\ Teague M. Embrey ${ }^{3}$, Debra L. Hughson ${ }^{4}$, Jane Cipra $^{5}$
}

I University of Nevada Las Vegas, School of Life Sciences, Las Vegas, Nevada 89154-4004, USA 2 National Park Service, Natural Resource Stewardship and Science Directorate, Climate Change Response Program, Fort Collins, Colorado 80525, USA 3 University of Nevada Las Vegas, Department of Environmental and Occupational Health, Las Vegas, Nevada 89154-3064, USA 4 National Park Service, Mojave National Preserve, Barstow, California 92311, USA 5 National Park Service, Death Valley National Park, Death Valley, California 92328, USA

Corresponding author: Scott R. Abella (scott.abella@unlv.edu)

Academic editor: M. Kleyer | Received 22 December 2014 | Accepted 5 May 2015 | Published 16 June 2015

http://zoobank.org/E7236F39-D8DA-4911-A990-F3CE133017AD

Citation: Abella SR, Fisichelli NA, Schmid SM, Embrey TM, Hughson DL, Cipra J (2015) Status and management of non-native plant invasion in three of the largest national parks in the United States. Nature Conservation 10: 71-94. doi: $10.3897 /$ natureconservation. 10.4407

\begin{abstract}
Globally, invasion by non-native plants threatens resources that nature reserves are designated to protect. We assessed the status of non-native plant invasion on 1,662, 0.1-ha plots in Death Valley National Park, Mojave National Preserve, and Lake Mead National Recreation Area. These parks comprise 2.5 million ha, $23 \%$ of the national park land in the contiguous USA. At least one non-native species inhabited $82 \%$ of plots. Thirty-one percent of plots contained one non-native species, $30 \%$ two, $17 \%$ three, and $4 \%$ four to ten non-native species. Red brome (Bromus rubens), an 'ecosystem engineer' that alters fire regimes, was most widespread, infesting $60 \%$ of plots. By identifying frequency of species through this assessment, early detection and treatment can target infrequent species or minimally invaded sites, while containment strategies could focus on established invaders. We further compared two existing systems for prioritizing species for management and found that a third of species on plots had no rankings available. Moreover, rankings did not always agree between ranking systems for species that were ranked. Presence of multiple non-native species complicates treatment, and while we found that $40 \%$ of plots contained both forb and grass invaders, exploiting accelerated phenology of non-natives (compared to native annuals) might help manage multi-species invasions. Large sizes of these parks and scale of invasion are formidable challenges for management. Yet, precisely because of their size, these reserves represent opportunities to conserve large landscapes of native species by managing non-native plant invasions.
\end{abstract}

Copyright Scott R. Abella et al. This is an open access article distributed under the terms of the Creative Commons Attribution License (CC BY 4.0), which permits unrestricted use, distribution, and reproduction in any medium, provided the original author and source are credited. 


\section{Keywords}

Exotic species, invasibility, invasive plants, multiple species, prioritization, elevation

\section{Introduction}

Non-native species are those transported intentionally or unintentionally by human activities to new areas (typically new continents) outside of their long-term evolutionary habitat (Schulz and Gray 2013). Nature reserves world-wide contain increasing numbers of non-native plant species in their flora (e.g., Allen et al. 2009, Barnett et al. 2007, Pyšek et al. 2003). Invasion by non-native plants occurred both before and after establishment of nature reserves. Even the world's oldest national park, Yellowstone established in 1872 in the USA, contained at least one non-native plant species in the initial 1886 inventory of the park (Whipple 2001). It now contains over 180 nonnative species. At least two non-native plant species inhabited Kruger National Park in South Africa when the park was first designated in 1898, and it now contains at least 257 non-native plant species (Foxcroft et al. 2008). Non-native species comprise 15\% of the flora in Czech Republic nature reserves (Pyšek et al. 2002), 6\% in Australia's Kakadu National Park (Cowie and Werner 1993), 11\% in Villarrica National Park in Chile (Pauchard and Alaback 2004), and 13\% in Gros Morne National Park in Canada (Rose and Harmanutz 2004).

If invading species were all innocuous and simply added to a reserve's biodiversity, there might be little cause for conern (Schlaepfer et al. 2011). Unfortunately, numerous examples exist of harmful non-native plants that can 'engineer' new habitat by creating/destroying ecosystem structure or modifying natural disturbance regimes, devastating native species (Foxcroft et al. 2013). Several observations portend reason for concern with ongoing invasion of nature reserves. Lag times - delays of decades to centuries between introduction of a species and exponential population growth - suggest that some currently sparse and innocuous species could become invasive (Theoharides and Dukes 2007). Moreover, short-term persistence of native species in invaded reserves might mask extirpations as eventual outcomes, indicating only part of the full impact of invasions is yet evident (Gilbert and Levine 2013). Plant invasions also can impact native biota in ways difficult to readily observe, such as inducing genetic change in native species (Leger 2008). On one hand, adaptation by native species to co-existing with a non-native might help natives persist, but on the other hand, genetic fitness for adaptation to other stressors (e.g., climate change) could be compromised. A precautionary approach would not assume that ongoing invasion will be innocuous (Andreu and Vilà 2010).

While the difficult task to curtail undesired species introductions between continents and into nature reserves needs further attention (Lodge et al. 2006), existing plant invasions are not necessarily hopeless situations due to some key aspects of invasion ecology. Existence of 'lag times' means that a relatively broad time window can be available for treating invaders before exponential population growth begins and 
treatment becomes arduous (Theoharides and Dukes 2007). Because high elevations of reserves are often least invaded, they represent locations managers can prioritize to keep relatively free of non-natives (Pauchard et al. 2009).

Identifying the non-native species present and their distribution is a first step in managing biological invasions (Barnett et al. 2007). For example, inventorying species abundance enables identifying which species are currently rare and thus manageable through early detection and treatment (Klinger et al. 2006). Requiring species inventory data, prioritization systems are under development in many areas and rank species for treatment based on factors such as species traits, impacts, and management difficulty (Andreu and Vilà 2010, Randall et al. 2008). Identifying sites invaded by multiple species is important, because invaders differing in phenology can necessitate multiple treatments at different times (Marushia et al. 2010).

Here, we collected and analyzed a unique data set of non-native plant species in three of the four largest national parks in the contiguous USA. The survey totaled 2.5 million ha, $8 \%$ of the total land area managed by the National Park Service and $23 \%$ of the USA's national park land outside of Alaska. Using a plot-based approach to assess over 1,600 sites, we examined the following questions: (1) How many nonnative plant species were detected and what were the most and least frequent species among parks? (2) How similar was non-native plant species composition among parks? (3) Were species prioritization rankings similar between ranking systems and related to relative abundance of species? (4) How many sites contained multiple non-native species, and which species co-occurred? (5) Were species distributions associated with elevation gradients and how similar were distributions among parks? Findings have implications for species distribution mapping, design of early detection and monitoring, and formulating non-native plant management plans for nature reserves.

\section{Methods}

\section{Study areas}

We conducted the study in three parks managed by the U.S. National Park Service: Death Valley National Park, Mojave National Preserve, and Lake Mead National Recreation Area, in the U.S. states of California, Nevada, and Arizona (Fig. 1). Each park exceeds 0.5 million ha and includes the largest national park in the lower 48 states (Death Valley), the third largest (Mojave), and the fourth largest (Lake Mead). These parks are in the Mojave Desert, where landforms include canyons, alluvial fans, cinder cones, low hills, mountains, dry lake beds, and intermittently flowing stream channels (Fig. 2). Predominant vegetation types include desert holly (Atriplex hymenelytra) and other shrub communities in the lowest-elevation basins, creosote bush-bursage (Larrea tridentata-Ambrosia dumosa) shrubland to elevations of $1200 \mathrm{~m}$, blackbrush (Coleogyne ramosissima) shrubland at middle elevations, single-leaf pinyon-Utah juniper (Pinus monophylla-Juniperus osteosperma) woodland starting around $1,600 \mathrm{~m}$ on mountain 


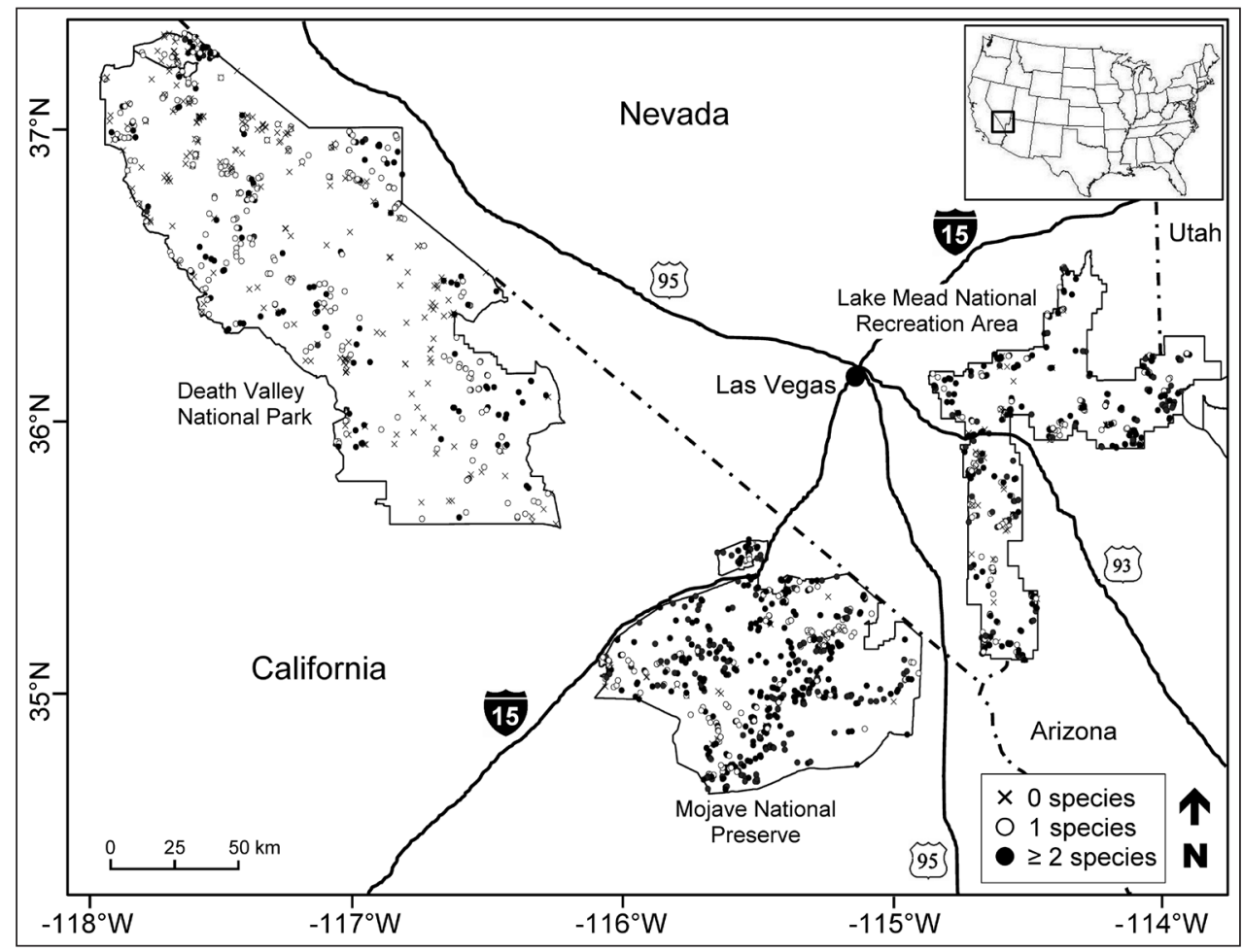

Figure I. Location of three parks managed by the National Park Service in which we measured nonnative plant species on 1,662 plots, Mojave Desert, southwestern USA.

slopes, and conifer forest such as white fir (Abies concolor) or bristlecone pine (Pinus longaeva) on the highest peaks (Keeler-Wolf 2007). Most annual plants are winter annuals, germinating in fall/winter (beginning in November) and growing until April (Beatley 1974).

Among the parks, Death Valley contains the lowest (along the Death Valley floor) and highest elevations (Telescope Peak in the Panamint Mountains; Table 1). Mojave Preserve contains low-lying basins and its highest elevations in the Clark Mountains, with much of the park of intermediate elevation (800-1500 m). Spirit Mountain, at $1,720 \mathrm{~m}$ in the Newberry Mountains, is the highest peak in Lake Mead National Recreation Area. Climate varies across the region and with elevation. The Death Valley, California, weather station at $58 \mathrm{~m}$ below sea level receives only $6 \mathrm{~cm} / \mathrm{yr}$ of precipitation and has an average January daily low temperature of $4{ }^{\circ} \mathrm{C}$ and July high of $47^{\circ} \mathrm{C}$ (1961-2012 records; Western Regional Climate Center, Reno, Nevada). In contrast, a station $1,326 \mathrm{~m}$ in elevation receives $27 \mathrm{~cm} / \mathrm{yr}$ of precipitation, with a January average daily low of $3{ }^{\circ} \mathrm{C}$ and July high of $34^{\circ} \mathrm{C}(1958-2011$; Mitchell Caverns, California, in south-central Mojave Preserve).

Before they were designated, the parks incurred anthropogenic disturbance including clearing for townsites, agriculture, or ranches in the 1800s and early 1900s; 


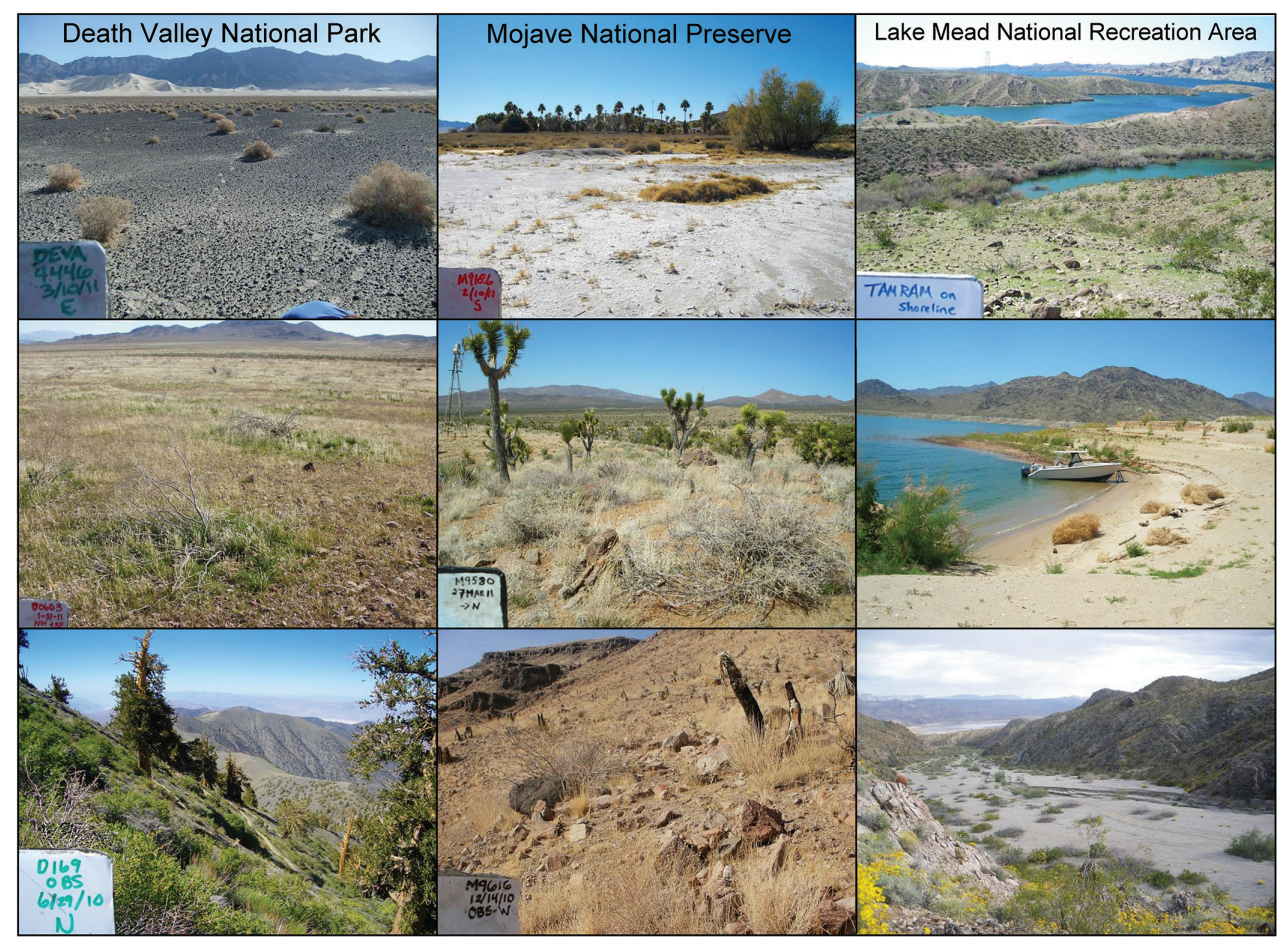

Figure 2. Views of national parks showing the variety of contexts in which non-native plants occur. Death Valley National Park: top: Death Valley floor where non-natives were generally sparse; middle: an area previously dominated by native shrubland and converted largely to non-native Bromus annual grassland following wildfire; bottom: Panamint Mountains where Bromus tectorum was the major nonnative species. Mojave National Preserve: top: developed area with a history of human occupation and disturbance (Zzyzx, California); middle: Yucca brevifolia-Coleogyne ramosissima mature native shrubland, among the most susceptible communities to wildfire spread facilitated by non-native grasses; bottom: this community type following wildfire. Lake Mead National Recreation Area: top: Tamarix spp. (tall, green, leafy trees) infesting riparian areas around the Lake Mead shoreline; middle: shoreline activities can distribute non-native plants, making treating non-natives along the shoreline a priority for park managers; bottom: natural washes can serve as vectors for dispersal of non-natives.

localized mining; alteration to springs and seeps (e.g., piping water elsewhere); road and trail building; and ranching operations with cattle and sheep (Lovich and Bainbridge 1999). Non-native burros were kept as work animals by miners and continue to inhabit these parks as feral animals (Beever and Pyke 2005). Livestock grazing allotments were decommissioned in the late 1990s in Lake Mead National Recreation Area and partially decommissioned from 1998-2002 in Mojave National Preserve. Extensive roadless areas exist, but the parks do contain widespread road networks, such as 3,700 $\mathrm{km}$ of roads within Mojave National Preserve (Vogel and Hughson 2009). Combined human visitation to the parks was 7.8 million visitors in 2012, including 1 million in Death Valley, 0.5 million in Mojave, and 6.3 million in Lake Mead (National Park Service, Public Use Statistics Office, Denver, Colorado). 
Table I. Characteristics of parks and sample plots for assessing non-native species distribution in National Park Service lands in the Mojave Desert, USA.

\begin{tabular}{l|c|c|c}
\hline & Death Valley & Mojave & Lake Mead National \\
\hline & National Park & National Preserve & Recreation Area \\
\hline Park characteristics & & & \\
\hline Size (ha) & $1,345,321$ & 643,112 & 563,513 \\
\hline Elevation range (m) & -86 to 3,368 & 270 to 2,417 & 158 to 1,720 \\
\hline Sample plots & & & \\
\hline No. plots & 623 & 600 & 493 \\
\hline Plot elevation range (m) & -86 to 3,329 & 276 to 2,416 & 158 to 1,704 \\
\hline Plots with $\geq 1$ non-native species (\%) & 65 & 95 & 78 \\
\hline Plots with $>1$ non-native species (\%) & 22 & 73 & 55 \\
\hline Plots with $>2$ non-native species (\%) & 3 & 32 & 28 \\
\hline Maximum non-native species/plot & 10 & 6 & 10 \\
\hline Non-native species/plot (mean \pm SEM) & $0.92 \pm 0.03$ & $2.05 \pm 0.04$ & $1.96 \pm 0.06$ \\
\hline Total non-native species on plots & 22 & 17 & 22 \\
\hline Park non-native species lists & & & 74 \\
\hline Total non-native species & 83 & 73 & \\
\hline
\end{tabular}

\section{Stratification for sampling}

We sampled all three parks using similar stratified-random designs. We divided Death Valley National Park into 16 zones corresponding to major mountain ranges (e.g., Panamint Mountains) or valleys (e.g., Death Valley floor). Using an existing vegetation map of the park (5-ha minimum mapping unit; Thomas et al. 2004) and a Geographic Information System random point generator (ArcGIS 9.3, Esri Corp., Redlands, California), we generated 5 potential points for sampling within each vegetation type. For instance, the largest zone (Last Chance Mountain Range) contained 43 vegetation types and had 215 potential sample points. Sample points were then evaluated and field visited in random order within zones, with the goal of sampling 2 (the first 2, if possible) of 5 potential sites. Potential points were rejected because of safety concerns (e.g., cliff faces were not sampled) or unsuitability (e.g., developed areas such as campgrounds), and the next potential point was evaluated.

We divided Mojave National Preserve into 31 zones according to broad landforms (e.g., Cima Volcanic Field) in a 1:100,000-scale geologic map (Miller et al. 1991). Then, to capture elevational variation, each zone was stratified by $250-\mathrm{m}$ elevation bands (e.g., 750-1,000 m). Finally, these elevation bands were stratified by predicted land cover based on the Thomas et al. (2004) vegetation map. Again using a random point generator, we selected three points for potential sampling within each vegetation type $\times$ elevation $\times$ landform zone stratum. Generation of three potential sample points within a stratum provided field crews the ability to reject unsuitable sites, as at Death Valley.

The Thomas et al. (2004) vegetation map did not extend to Lake Mead National Recreation Area, so the park was stratified into $1-\mathrm{km}^{2}$ pixels based on climate (derived 
from PRISM), topography (digital elevation models), and soil parent material (Lato 2006). Climate layers included July average maximum temperature $\left(>41{ }^{\circ} \mathrm{C}, \leq 41{ }^{\circ} \mathrm{C}\right)$, January average minimum temperature $\left(>2.5^{\circ} \mathrm{C}, \leq 2.5^{\circ} \mathrm{C}\right)$, average annual May through October precipitation $(>8 \mathrm{~cm}, \leq 8 \mathrm{~cm})$, and average annual November through April precipitation $(6-9 \mathrm{~cm}, 9-11 \mathrm{~cm}$, and 11-16 cm). Topography was categorized as drainage, flat (< $1 \%$ slope gradient), gently sloping ( 1 to $\leq 10 \%$ gradient), and for slope gradients $>10 \%$, by slope aspect as northeast $\left(0-89^{\circ}\right)$, southwest $\left(180-269^{\circ}\right)$, or neutral $\left(90-179^{\circ}\right.$ or $\left.270-359^{\circ}\right)$. There were 188 unique combinations of these variables extant on the landscape, and 2-3 points were randomly sampled per combination.

\section{Data collection}

We used the same procedures for field data collection in all three parks. At each sample point, we surveyed a square plot of 0.1 ha for areal cover of non-native plant species (including annual, biennial, and perennial plants) using the following cover classes: present but < 1\%, 1-5\%, > 5-15\%, > 15-25\%, > 25-50\%, > 50-75\%, and > 75\%. We recorded both live and dead annual plants as a measure of cumulative presence for two reasons: 1) live annual plants are ephemeral, absent many years and when present, for only a short time in winter/spring; and 2) fuel provided by dead annual plants poses a fire hazard to mature Mojave Desert plant communities (Brisbin et al. 2013). The length of time that dead annuals persist as upright stalks varies, but Beatley (1966) noted that red brome (Bromus rubens), a major non-native in the Mojave Desert, can stand approximately two years. We summed cover of live and dead stalks of annual plants into a single cover estimate by species for each plot. Nomenclature and classification of species by longevity/growth forms (e.g., perennial forb) and native/exotic followed Natural Resources Conservation Service (2013).

We established a total of 1,662 plots that encompassed $99 \%$ of elevation ranges within parks (Table 1). We sampled high elevations in warmer months and low elevations in cooler months. We worked in Death Valley National Park between May 17 and July 2, 2010, and between January 4 and May 22, 2011. Between September 30, 2010 and June 7, 2011, we sampled Mojave National Preserve. We sampled Lake Mead National Recreation Area between February 18 and May 13, 2010, and between September 9 and October 22, 2010.

\section{Data analysis}

For all plots combined and each park separately, we calculated the total number of non-native species, percentage of plots containing one or more non-native species, mean non-native richness (species/0.1-ha plot), and frequency of each species. We used Pearson correlation coefficients to examine relationships between elevation and nonnative species richness and cover. We compared species prioritization rankings from 
two systems: NatureServe's I-rank (Randall et al. 2008) and the California Invasive Plant Council system (Cal-IPC; Warner et al. 2003). To compare species recorded on plots with all known records of non-native species within each park, we obtained species lists maintained by each park. Using PC-ORD v. 6 (McCune and Mefford 1999), we calculated Sørensen similarities between parks of species composition (presence/ absence data) recorded on plots and from park species lists.

\section{Results}

\section{All plots across parks}

Eighty-two percent of plots contained at least one non-native plant species (Table 1, 2). Non-native richness ranged from $0-10$ species $/ 0.1$ ha, with a median of 2 species and mean of $1.60 \pm 0.03$ ( \pm standard error of mean). Thirty-one percent of plots contained one non-native species, $30 \%$ two, $17 \%$ three, and $4 \%$ four to ten species. For example, considering two species of Bromus, $36 \%$ of plots contained neither species, $3 \%$ only cheatgrass (Bromus tectorum), $50 \%$ only Bromus rubens, and $10 \%$ both (Fig. 3). Total non-native cover ranged from $0-81 \%$, with a median of $0.4 \%$ and mean of $2.5 \pm 0.1 \%$. Most plots had low cover and few had high cover: $60 \%$ had $<1 \%$ cover, $26 \%$ had $1-5 \%, 8 \%$ had $5-10 \%$, and $6 \%$ had $>10 \%$ cover.

Of 29 total non-native species on plots, 59\% were annuals, $10 \%$ annuals/biennials, $14 \%$ annual to perennials, and $17 \%$ perennials (Table 2). By growth form, $55 \%$ were forbs, $35 \%$ grasses, $7 \%$ shrubs, and $3 \%$ trees. Annual forbs (31\%) and annual grasses $(28 \%)$ were the most prevalent groups. The most frequent species included: Bromus rubens (60\% of plots), redstem filaree (Erodium cicutarium; 39\%), Schismus spp. (28\%), Bromus tectorum (13\%), prickly Russian thistle (Salsola tragus; 4\%), Sahara mustard (Brassica tournefortii; 4\%), and saltcedar (Tamarix ramosissima; 3\%).

Results were mixed regarding availability of species prioritization rankings, consistency between ranking systems, and relationship between a species' rank and its frequency (Table 2). Nineteen of 28 taxa (68\%, with Schismus spp. grouped to genus) had rankings available from the Cal-IPC system and 17 were ranked by the NatureServe I-rank system. There were six species $(21 \%)$ not ranked by either. Of the 9 taxa ranked by both systems, consistency varied. Ranking was consistent for Bromus tectorum and Tamarix ramossisma, with both systems ranking the species as high priority and capable of pervasive impacts. However, the two systems returned opposite rankings for Schismus spp. Cal-IPC ranked the taxon as 'low' priority, while NatureServe ranked it as 'high' priority.

We did not detect an overall correlation between elevation and non-native richness or cover (Fig. 4). The only trend apparent was that all plots containing $>2$ non-native species occurred at elevations $<2,000 \mathrm{~m}$. Individual species displayed stronger relationships with elevation than did total non-native measures (Fig. 5). Brassica tournefortii and Schismus spp. were most frequent at elevations below 1,200 m. Although infesting 


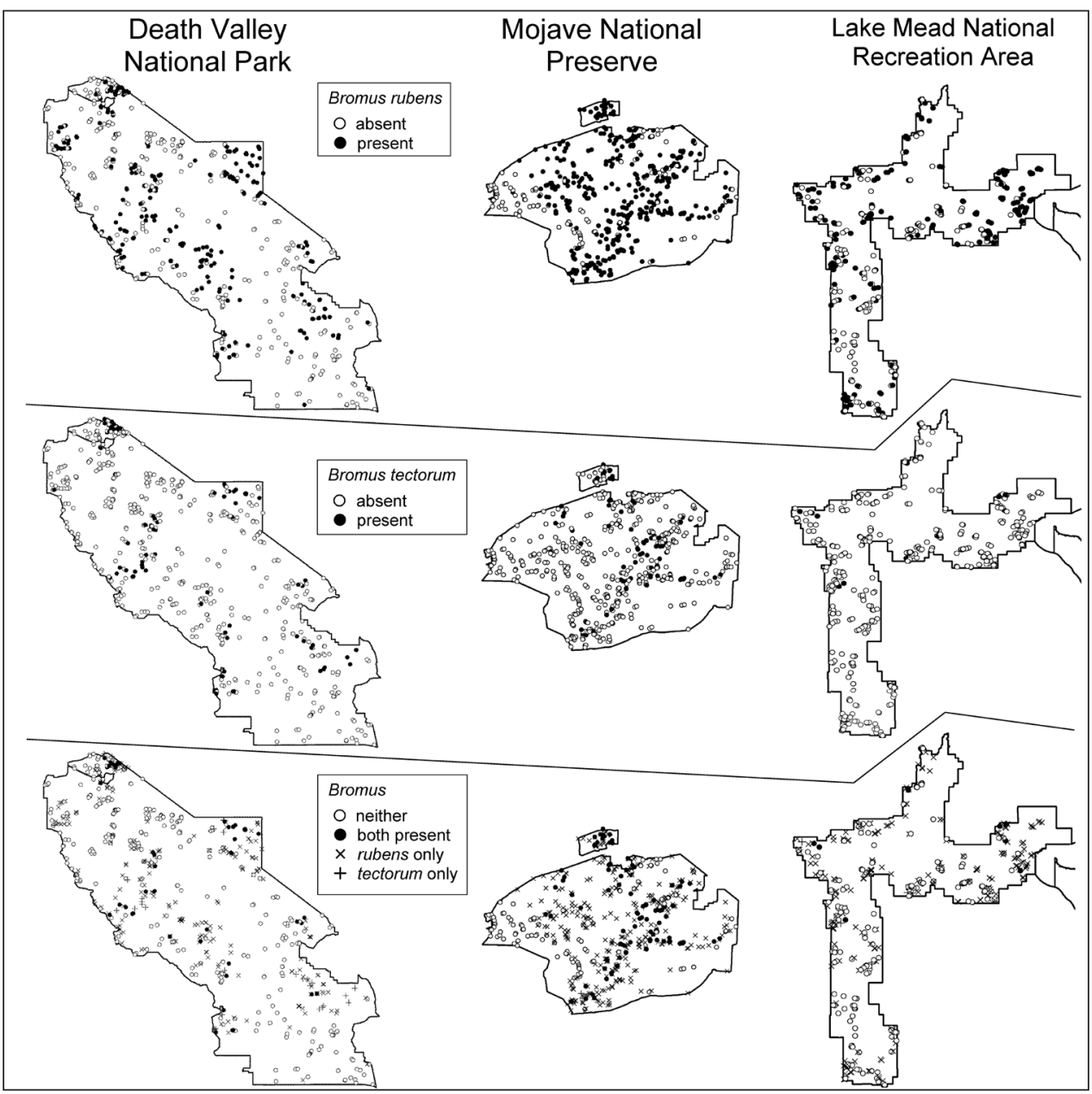

Figure 3. Presence or absence of the non-native annuals Bromus rubens and Bromus tectorum in national park units of the Mojave Desert, southwestern USA.

a broad elevation range, Erodium cicutarium was most frequent at middle elevations between 400 and 1,600 m. Distribution of the most frequent species, Bromus rubens, also was centered on middle elevations. Bromus tectorum exhibited a different pattern: it was most frequent at elevations above 1,600 $\mathrm{m}$ in Death Valley National Park and Mojave National Preserve, and at the highest elevations present in Lake Mead National Recreation Area.

\section{Comparison of parks}

The total number of non-native species detected on plots within parks was similar, ranging from 17-22 species/park (Table 1). However, mean non-native richness/plot was 


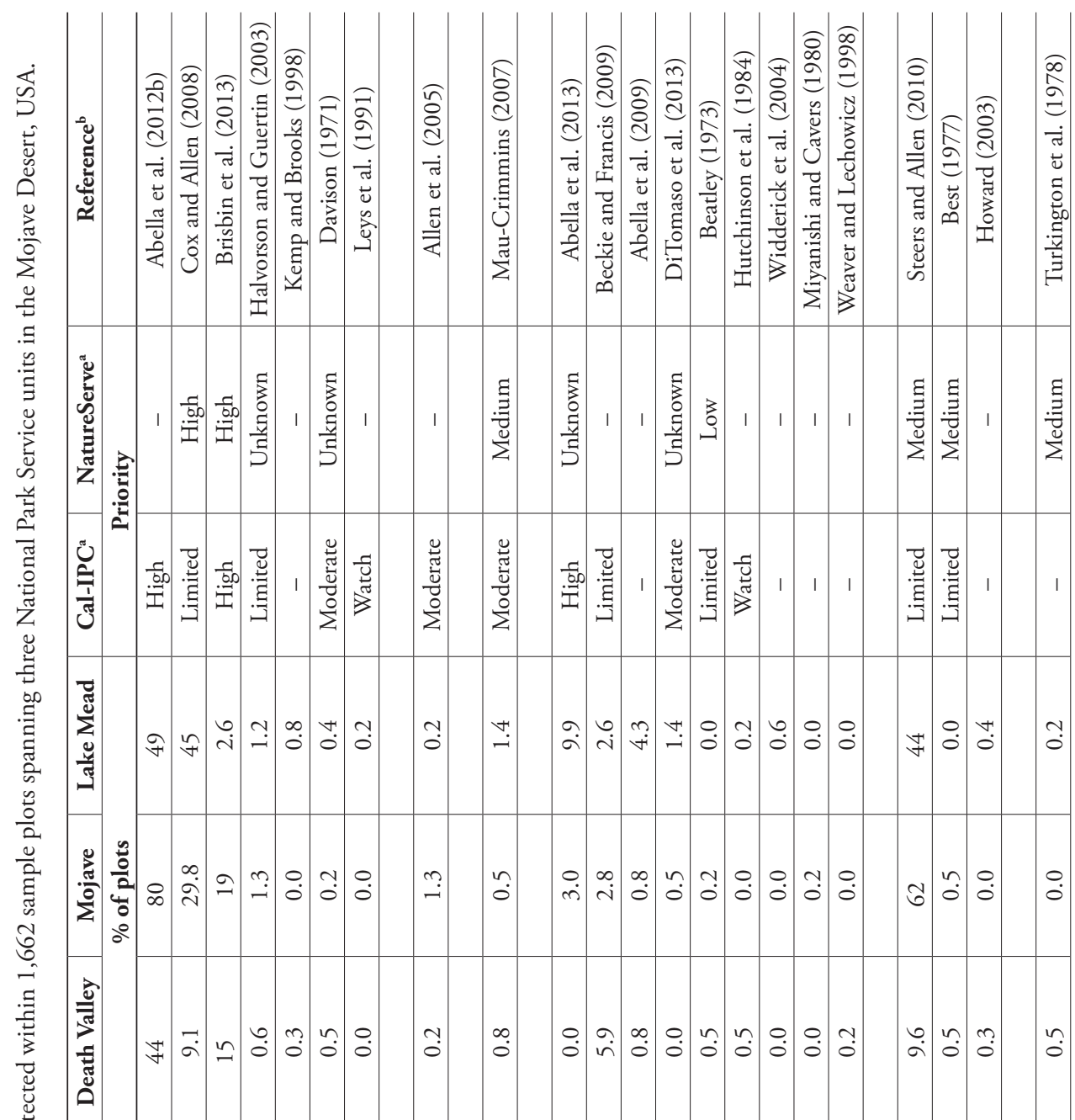

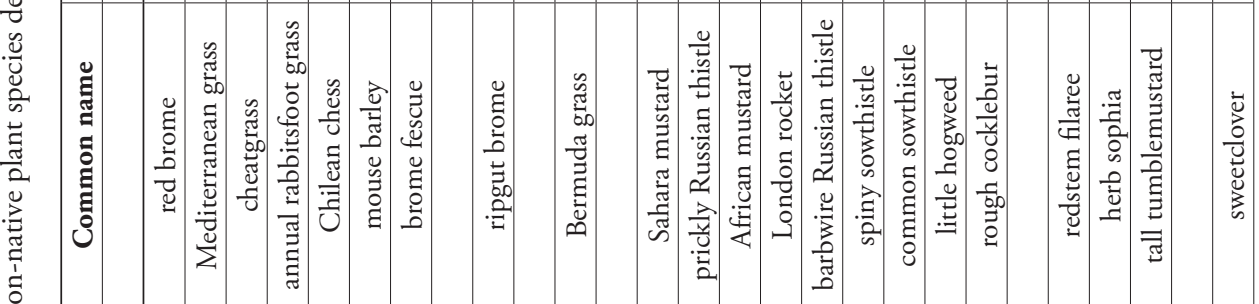

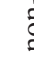
ปे 


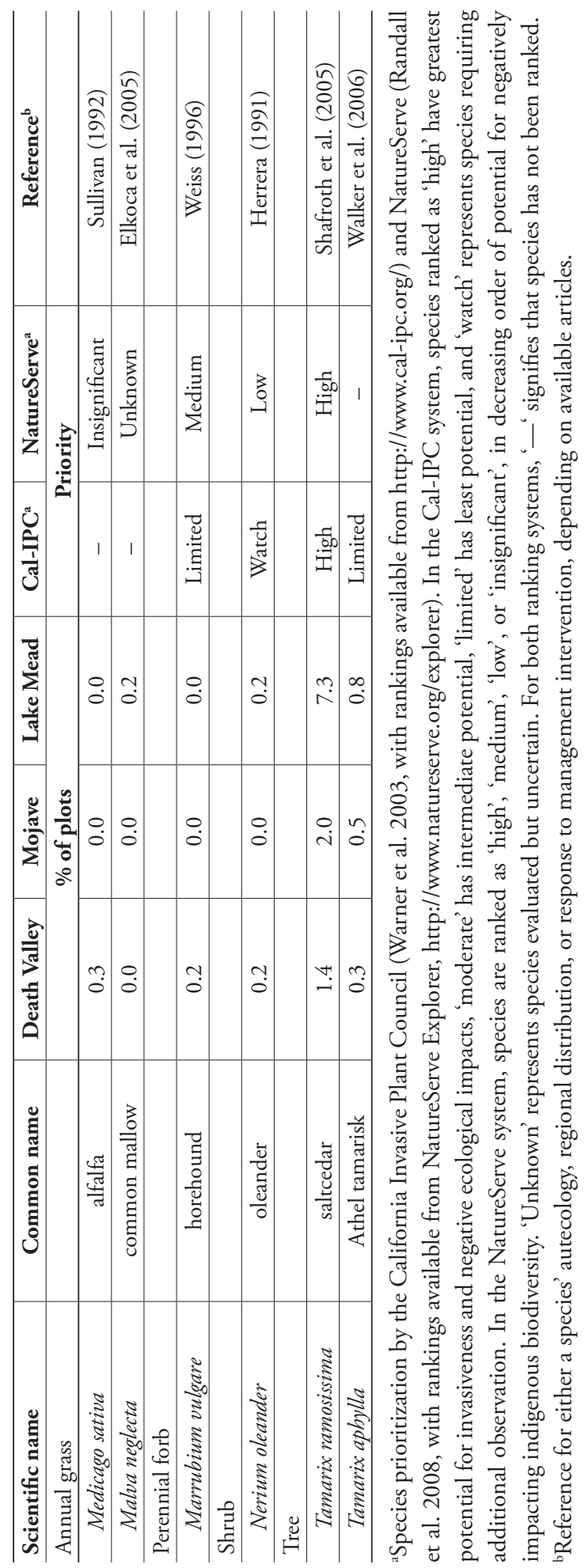




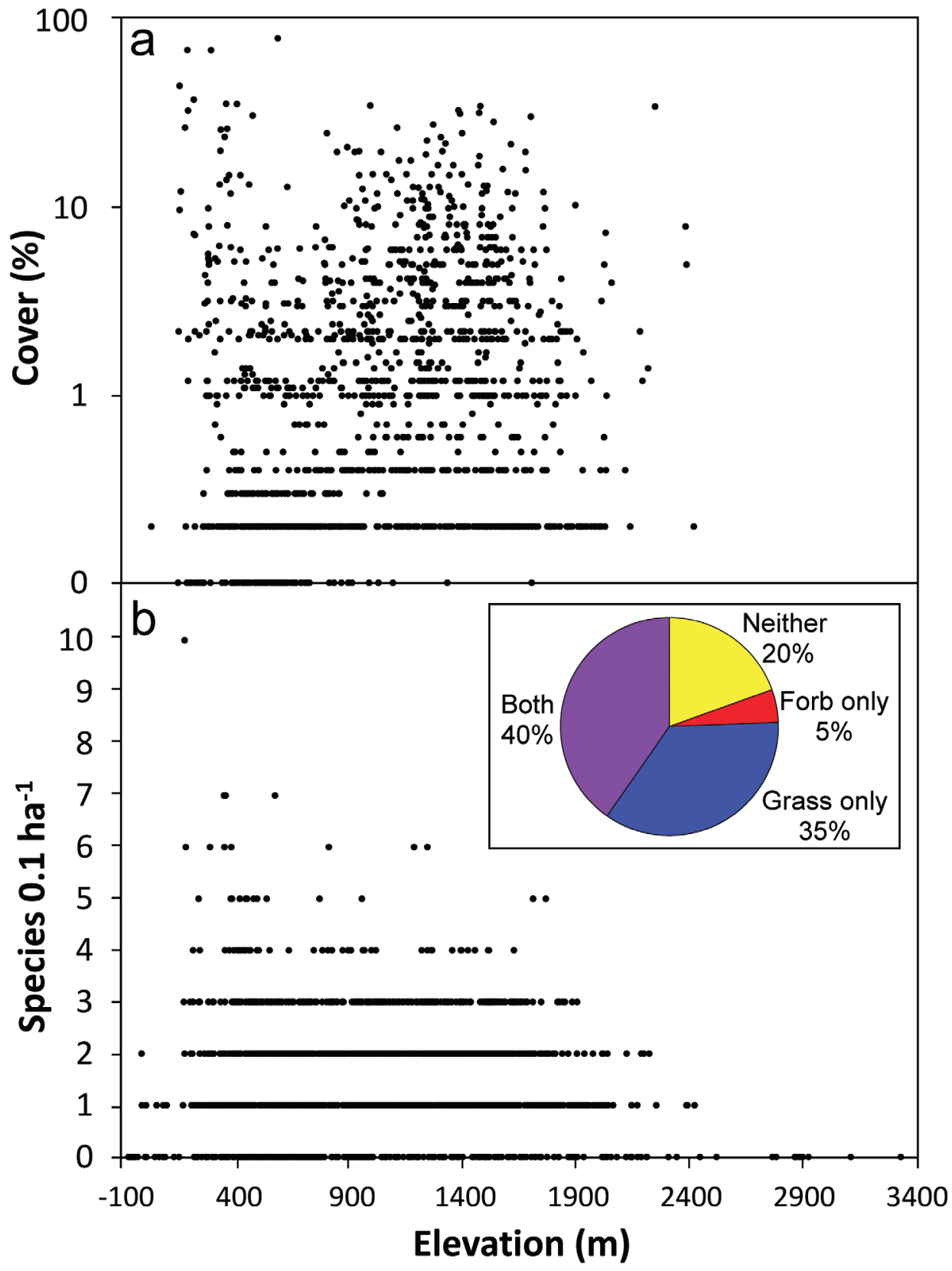

Figure 4. Scatterplot of elevation and non-native plant species richness and cover derived from 1,662 plots in Death Valley National Park, Mojave National Preserve, and Lake Mead National Recreation Area in the Mojave Desert, southwestern USA. There was no relationship between elevation and non-native richness or cover (Pearson $r=0.00$ ). The inset graph in (b) shows percentages of plots infested by either non-native grasses or forbs, or both ('neither' signifies $18 \%$ of plots not invaded and $2 \%$ invaded only by woody species). 


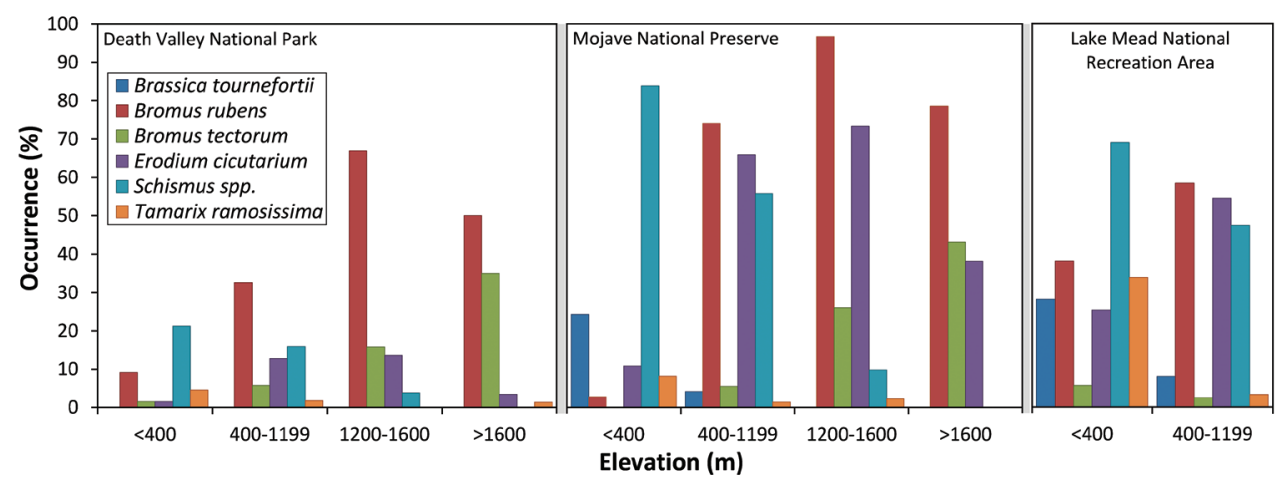

Figure 5. Relationship between elevation and frequency of major non-native plant species in three Mojave Desert parks, southwestern USA. High elevations were absent in Lake Mead.

Table 3. Sørensen similarities of non-native species composition among parks for plots (no parentheses) and park species lists (inside parentheses) in the Mojave Desert, USA.

\begin{tabular}{c|c|c}
\hline & Death Valley & Mojave \\
\hline & \multicolumn{2}{|c|}{ Similarity $(\%)$} \\
\hline Mojave & $73(51)$ & - \\
\hline Lake Mead & $57(51)$ & $76(60)$ \\
\hline
\end{tabular}

twice as high in Mojave National Preserve and Lake Mead National Recreation Area as in Death Valley National Park. Mojave Preserve had the fewest un-invaded plots and 3x as many plots containing at least two non-native species as did Death Valley.

Bromus rubens was the most frequent species in all three parks, and its highest frequency was in Mojave National Preserve (Table 2). Notable differences in species frequencies included low frequency of Schismus spp. and Erodium cicutarium in Death Valley relative to the other parks, and higher frequency of Bromus tectorum in Death Valley and Mojave compared to Lake Mead. Additionally, Brassica tournefortii was not detected on any plots in Death Valley, whereas the species was the fourth most frequent at Lake Mead.

\section{Park species lists}

Lists maintained by each park contained similar numbers of non-native species, ranging from 73-83 species (Table 1). The percentage of a park's non-native flora detected on plots was also similar among parks at 23-30\%. Most species on plots were on these lists except for some new records that the plots produced: Chilean chess (Bromus berteroanus) and alfalfa (Medicago sativa) in Death Valley, and common mallow (Malva neglecta) in Mojave Preserve. Compositional similarity of non-native species lists was $51-60 \%$ among parks, slightly lower than the $57-76 \%$ similarity for plots among parks (Table 3). 


\section{Discussion}

This assessment suggested that: (i) the parks contain relatively few frequent species, yet these frequent species, mostly annuals, are present on most of the landscape; (ii) non-native plant composition was similar among parks, but non-native frequency was greatest in Mojave National Preserve; (iii) existing species prioritization systems ranked $80 \%$ of species and were not always consistent; (iv) over half (51\%) of plots contained multiple non-native species; and (v) only elevation extremes tended not to harbor multiple non-native species.

\section{Invasion status}

Present invasion status of these parks could be interpreted from different viewpoints. On one hand, the fact that $82 \%$ of plots were invaded by at least one non-native species is alarming. Moreover, the ecosystem engineer, Bromus rubens, occurred in $60 \%$ of plots. By providing copious and persistent fuel, this species promotes spread of wildfire, a novel disturbance requiring centuries for recovery of mature perennial communities in this desert (Abella 2010, Steers and Allen 2010). Some other frequent species, such as Tamarix ramosissima, also can dramatically impact indigenous ecosystems, including riparian areas which are hotspots of native biodiversity (Shafroth et al. 2005). On the other hand, $60 \%$ of plots had $<1 \%$ cover, indicating extensive minimally infested area.

Plot-based surveys of landscapes like ours provide information on species distribution and abundance and are not exhaustive botanical inventories (Barnett et al. 2007). Our plots contained $21 \%$ of the 139 non-native species on inventory lists of these parks. Our study years were near average for detecting annual plants, based on receiving $132 \%$ of long-term average (74 years) precipitation for the 2010 growing season (October 2009 through April 2010) and 104\% for the 2011 growing season (October 2010 through April 2011; Las Vegas, Nevada airport station). Many of the undetected species are uncommon in the backcountry and inhabit only specific sites, such as campgrounds, roadsides, and cultural areas (e.g., historical cabins including non-native landscaping vegetation, or orchards).

Although non-native species measures such as total species and species composition were generally similar among parks, some notable differences existed. Mojave National Preserve had the fewest un-invaded plots, and Death Valley National Park had the lowest non-native richness/plot and fewest plots containing multiple species. Mojave Preserve has the most extensive history of disturbance and was most recently placed under National Park Service protection in 1994 (Beever and Pyke 2005). In the Czech Republic, the later reserves were created, the more non-native plants they contained (Pyšek et al. 2003). Mojave Preserve also has extensive middle elevations most susceptible to non-native plant fuel production and wildfire spread (Van Linn et al. 2013). Less invasion in Death Valley might relate to the park containing elevation extremes, which were least invaded, and the lowest frequencies of Schismus spp. 
and Erodium cicutarium. Another difference was that Lake Mead contained the lowest frequency of Bromus tectorum, likely because high elevations were absent (Abella and Tendick 2013).

\section{Elevation}

Although correlations between elevation and non-native richness and cover were not detected, individual species were most frequent within particular elevation ranges. Additionally, elevation extremes (below sea level and $>2,000 \mathrm{~m}$ ) were least invaded in terms of non-native species richness. If climate becomes warmer and drier in the region as some projections suggest (Barrows and Murphy-Mariscal 2012), lower elevations might become even less invasible, and higher elevations more so. Forecasting how invasibility might change at high elevations is difficult, because high elevations may already be invasible and simply have not received seed pressure (Keeley et al. 2003). In Rocky Mountain National Park, Colorado, Bromus tectorum frequency increased by 50\% across high-elevation ecotonal plots over a 12-year period from 1996-2007 that was relatively dry (Bromberg et al. 2011). Given minimal invasion at the highest elevations in our study parks, early detection and treatment of new invaders and newly invaded sites might be particularly appropriate.

\section{Non-native plant impacts: the desert tortoise and species evolution}

Unfortunately, the most frequently detected species, such as Bromus rubens, are not simply 'innocuous' inhabitants of the parks, but rather the most damaging type of non-native species (i.e. ecosystem engineers; Crooks 2002). These non-natives can disrupt critical ecological functions, fundamentally conflicting with the national park goal of promoting native species and processes. One such example warranting further attention is food availability to the desert tortoise (Gopherus agassizii). This long-lived $(\sim 50$ years) reptile inhabits all three parks and is listed as threatened under the U.S. Endangered Species Act. Two studies in the Mojave Desert reported that despite being among the most abundant plants, the non-native Schismus spp. and Bromus rubens were avoided by foraging tortoises (Jennings 1997, Oftedal et al. 2002). Although Schismus spp. represented $98 \%$ of the plants encountered, tortoises ate $<0.1 \%$ of them (Oftedal et al. 2002). Compared to native annual forbs, Schismus has lower water and protein content and high potassium toxicity. Moreover, the pointed florets of Bromus can injure tortoises directly when ingested (Medica and Eckert 2007). Non-native annuals compete with native annual forage plants, and natives have increased when Schismus and Bromus were removed (Brooks 2000). Declining populations of desert tortoises face pervasive dominance of non-preferred food plants, which further influence habitat conditions by providing fuel facilitating spread of desert wildfires (Brooks and Berry 2006). 
Our results showing how widespread invading species are on these landscapes exemplify a broad issue of biological invasions being a driver of contemporary species evolution (Leger and Espeland 2010). Two examples from our set of invading species illustrate this. Within 7 years of being exposed to elevated $\mathrm{CO}_{2}$, Bromus rubens plants evolved lower rates of leaf stomatal conductance, a physiological adaptation linked with improved water-use efficiency (Grossman and Rice 2014). Most of the invading species in southwestern deserts are annuals, such as Bromus, able to rapidly evolve (Table 2). This underscores the importance of management actions to reduce population sizes of non-natives and their capacity for evolving traits that make them even more competitive (Leger and Espeland 2010). Genetics of native species may also be shifting in response to environments altered by non-native plants. In the Great Basin Desert, growth of native perennial grasses responded most rapidly to watering on sites that were most heavily invaded by Bromus tectorum (Leger 2008). This implied that native plants were adapting to become more competitive with Bromus (Leger 2008). Adaptation to the presence of a non-native species may be beneficial for persistence of some native plants. However, it is undesirable from a national park perspective, where native species are supposed to evolve through natural processes, not through anthropogenic species introductions.

\section{Implications for species mapping and management planning}

These assessment data are an initial step towards non-native plant distribution mapping, which needs to consider extreme spatio-temporal variability in desert ephemeral plants. Distribution and abundance of annual plants varies both with inherent site productivity and weather in any particular year (Wallace and Thomas 2008, Casady et al. 2013). In addition to being a practical strategy given difficulty in sampling numerous desert sites in a short spring growing season, we included live and dead annual plants to both represent cumulative recent 'presence' and importance of live and dead biomass as fuel. Thus, the survey data could facilitate spatial modeling of site productivity for these species across the landscape, and serve as baseline data for modeling temporal variation.

Our findings revealed several considerations regarding species prioritization as a management tool. Not all species of management interest had 'off the shelf rankings available, necessitating that managers develop their own rankings, a difficult task for little-studied species. Even if a species has no ranking available, existing ranking systems may still offer a useful framework for developing customized rankings. Results also suggested that comparing different ranking systems, when available, is useful to assess consistency of rankings (Andreu and Vilà 2010). Rankings can differ for numerous reasons, such as different emphases (e.g., inclusion or exclusion of management difficulty as an evaluation factor), and date of the ranking which affects information available. As one example, our comparisons illustrated that Schismus spp. were ranked oppositely ('low' and 'high' priority) by two ranking systems (Randall et al. 2008, 
Warner et al. 2003). In addition to providing fuel for wildfire and competing with native plants (Abella and Smith 2013), the observation that Schismus is non-preferred forage for the desert tortoise suggests that the 'low' ranking for Schismus warrants reevaluation (Oftedal et al. 2002).

Prioritizing species currently at the extremes - those that are infrequent (but capable of impacts) and those that are widespread and capable of major impacts - may maximize use of limited treatment resources. For example, early treatment of currently infrequent species such as ripgut brome (Bromus diandrus) and spiny sowthistle (Sonchus asper) would follow a principle that early detection and treatment is the most cost-effective and successful strategy (Lodge et al. 2006). This also helps reduce risk that these species become future problems.

Rather than viewing pervasive, high-impact invaders like Bromus rubens as 'hopeless', treating these species at priority sites is likely important to avoid negating other management efforts and indeed protecting core values of parks. Over 28,700 ha (4.5\%) of Mojave National Preserve burned in fires partly fueled by Bromus rubens between 2005 and 2011, destroying mature desert vegetation, as well as cultural resources (Hegeman et al. 2014). Strategically treating priority sites can reduce landscape fuel connectivity (Brisbin et al. 2013). Treatments suitable for broad areas such as those infested by Bromus rubens require further experimentation, but early timed herbicide application has reduced Bromus while promoting natives (Allen et al. 2005). Competitive native species also can reduce Bromus (Abella et al. 2012), and biocontrol agents are under evaluation (Baughman and Meyer 2013).

We identified sites containing multiple non-native plant species, which can affect candidate treatment strategies and their effectiveness. The potential influences of multiple species are numerous, such as: (i) herbicide effectiveness can vary with plant growth form, (ii) treatment timing can be difficult when species' phenologies differ, (iii) required treatment duration can fluctuate among species varying in soil seed bank longevity, (iv) more complicated treatment regimes can increase costs and potential for negatively impacting native species, and (v) chances increase that other non-native species replace a focal treated species (Abella 2014).

What evidence exists for relationships of multiple species with treatment difficulty in the Mojave Desert? Brooks (2000) found that hand pulling Bromus rubens or Schismus spp. increased native annuals but also increased the non-native forb Erodium cicutarium. Similarly, hand weeding Brassica tournefortii increased Erodium (Marushia et al. 2010). In a post-fire environment dominated by non-native annuals, Steers and Allen (2010) had more encouraging results where herbicide not only reduced the grasses Bromus and Schismus, it also reduced Erodium. Native annual forbs increased, and the native grass sixweeks fescue (Vulpia octoflora) was not damaged (Steers and Allen 2010). The treatments exploited the accelerated early season phenology of non-native annuals (compared to native annuals) by applying herbicide early in the growing season. Refining knowledge of the earliest possible time for treating non-natives - which might vary among years - is warranted to manage single- and multi-species infestations while promoting natives (Marushia et al. 2010, Abella et al. 2013). 


\section{Conclusion}

Invasion by non-native species is generally inconsistent with national park objective of conserving native species and ecological processes (National Park Service 2006). Our assessment illustrated that non-native plants infested $82 \%$ of 1,662 plots in three of the four largest national parks in the contiguous USA. Given numerous priorities for management, how much attention do non-native plants warrant? We suggest that greater attention is warranted, because non-native plant invasions can impact essentially all functions of parks, ranging from nature conservation to visitor experiences and viewsheds (Lodge et al. 2006). Furthermore, non-native species can interact with other stressors such as climate change. In Joshua Tree National Park in the southern Mojave Desert, for example, Barrows and Murphy-Mariscal (2012) reported that projected future habitat of the park's namesake (Joshua tree, Yucca brevifolia, a fire-susceptible species) in a changing climate would continue to correspond with that of the fire-promoting, nonnative annual Bromus rubens. With continuation of novel fire regimes, it is unclear how many Yucca trees may still be around to even experience a future climate.

At least three strategies may facilitate reducing non-native plant invasion. First, given the limited and short duration of funding allocated to treating non-native plants, 'institutionalizing' non-native plant management in park operations is likely critical. For example, infusing knowledge of non-native plants into visitor education and developing systems for park staff and visitors to report infestations while moving through parks can be cost-effective (Crall et al. 2012). Second, owing to interrelatedness of non-native species and other stressors, treating non-natives while managing other stressors (e.g., nitrogen deposition via air pollution) may increase ecological effectiveness and cost-efficiency. Third, dedicating further resources to managing non-native plants may be essential to protect core park values. It should be recognized that dedicating resources to treating non-native plants in most national parks is recent, such as formation in 2000 of the National Park Service's Exotic Plant Management Teams. Moreover, enormous parks such as the ones of our study do not necessarily receive more resources than parks $<1 \%$ their size, and this size:resource imbalance may require attention. Existing non-native plant invasion is unlikely to represent a 'hopeless' situation for native species conservation in our study parks, because $60 \%$ of plots had $<1 \%$ cover of non-native plants.

\section{Acknowledgements}

The National Park Service, Inventory and Monitoring Program (IMP), funded data collection through a grant to S.R. Abella via a cooperative agreement between the University of Nevada Las Vegas and the Mojave Network IMP. Natural Resource Conservation LLC donated time to prepare the manuscript. David Salas (Bureau of Reclamation) developed the sampling stratification for Lake Mead National Recreation Area (LMNRA). We thank Kathryn Prengaman, Joslyn Curtis, Karin Edwards, Julia 
Gehring, Shannon Henke, and Carl Howard for help with fieldwork; Jeanne Taylor for coordinating the project while with IMP; Sharon Altman for creating the figures; Alice Newton and Carrie Norman for logistical support for sampling LMNRA and providing a non-native plant list; and Sharon Altman and Michael Kleyer for helpful comments on the manuscript.

\section{References}

Abella SR (2014) Effectiveness of exotic plant treatments on National Park Service lands in the United States. Invasive Plant Science and Management 7: 147-163. doi: 10.1614/ IPSM-D-13-00058.1

Abella SR, Suazo AA, Norman CM, Newton AC (2013) Treatment alternatives and timing affect seeds of African mustard (Brassica tournefortii), an invasive forb in American Southwest arid lands. Invasive Plant Science and Management 6: 559-567. doi: 10.1614/IPSM-D-13-00022.1

Abella SR, Craig DJ, Smith SD, Newton AC (2012) Identifying native vegetation for reducing exotic species during the restoration of desert ecosystems. Restoration Ecology 20: 781787. doi: 10.1111/j.1526-100X.2011.00848.x

Abella SR (2010) Disturbance and plant succession in the Mojave and Sonoran Deserts of the American Southwest. International Journal of Environmental Research and Public Health 7: 1248-1284. doi: 10.3390/ijerph7041248

Abella SR, Tendick A (2013) Distribution of exotic plant species and relationship to vegetation type at Bryce Canyon National Park, USA. Landscape and Urban Planning 120: 48-58. doi: 10.1016/j.landurbplan.2013.08.010

Abella SR, Smith SD (2013) Annual-perennial plant relationships and species selection for desert restoration. Journal of Arid Land 5: 298-309. doi: 10.1007/s40333-013-0172-0

Allen EB, Cox RD, Tennant T, Kee SN, Deutschman DH (2005) Landscape restoration in southern California forblands: response of abandoned farmland to invasive annual grass control. Israel Journal of Plant Sciences 53: 237-245. doi: 10.1560/65LM-55YH-GB49-5BJM

Allen JA, Brown CS, Stohlgren TJ (2009) Non-native plant invasions of United States national parks. Biological Invasions 11: 2195-2207. doi: 10.1007/s10530-008-9376-1

Andreu J, Vilà M (2010) Risk analysis of potential invasive plants in Spain. Journal for Nature Conservation 18: 34-44. doi: 10.1016/j.jnc.2009.02.002

Barnett DT, Stohlgren TJ, Jarnevich CS, Chong GW, Ericson JA, Davern TR, Simonson SE (2007) The art and science of weed mapping. Environmental Monitoring and Assessment 132: 235-252. doi: 10.1007/s10661-006-9530-0

Barrows CW, Murphy-Mariscal ML (2012) Modeling impacts of climate change on Joshua trees at their southern boundary: how scale impacts predictions. Biological Conservation 152: 29-36. doi: 10.1016/j.biocon.2012.03.028

Beatley JC (1966) Ecological status of introduced brome grasses (Bromus spp.) in desert vegetation of southern Nevada. Ecology 47: 548-554. doi: 10.2307/1933931

Beatley JC (1973) Russian-thistle (Salsola) species in western United States. Journal of Range Management 26: 225-226. doi: 10.2307/3896700 
Beatley JC (1974) Phenological events and their environmental triggers in Mojave Desert ecosystems. Ecology 55: 856-863. doi: 10.2307/1934421

Beckie HJ, Francis A (2009) The biology of Canadian weeds. 65. Salsola tragus L. (Updated). Canadian Journal of Plant Science 89: 775-789. doi: 10.4141/CJPS08181

Baughman OW, Meyer SE (2013) Is Pyrenophora semeniperda the cause of downy brome (Bromus tectorum) die-offs? Invasive Plant Science and Management 6: 105-111. doi: 10.1614/ IPSM-D-12-00043.1

Beever EA, Pyke DA (2005) Short-term responses of desert soil and vegetation to removal of feral burros and domestic cattle (California). Ecological Restoration 23: 279-280.

Best KF (1977) The biology of Canadian weeds. 22. Descurainia sophia (L.) Webb. Canadian Journal of Plant Science 57: 499-507. doi: 10.4141/cjps77-073

Brisbin H, Thode A, Brooks M, Weber K (2013) Soil seedbank responses to postfire herbicide and native seeding treatments designed to control Bromus tectorum in a pinyon-juniper woodland at Zion National Park, USA. Invasive Plant Science and Management 6: 118-129. doi: 10.1614/IPSM-D-12-00048.1

Bromberg JE, Kumar S, Brown CS, Stohlgren TJ (2011) Distributional changes and range predictions of downy brome (Bromus tectorum) in Rocky Mountain National Park. Invasive Plant Science and Management 4: 173-182. doi: 10.1614/IPSM-D-10-00022.1

Brooks ML (2000) Competition between alien annual grasses and native annual plants in the Mojave Desert. American Midland Naturalist 144: 92-108. doi: 10.1674/0003-0031(2000)144[0092:CBAAGA]2.0.CO;2

Brooks ML, Berry KH (2006) Dominance and environmental correlates of alien annual plants in the Mojave Desert, USA. Journal of Arid Environments 67: 100-124. doi: 10.1016/j. jaridenv.2006.09.021

Casady GM, van Leeuwen WJD, Reed BC (2013) Estimating winter annual biomass in the Sonoran and Mojave Deserts with satellite- and ground-based observations. Remote Sensing 5: 909-926. doi: 10.3390/rs5020909

Cowie ID, Werner PA (1993) Non-native plant species invasive in Kakadu National Park, tropical northern Australia. Biological Conservation 63: 127-135. doi: 10.1016/00063207(93)90500-Z

Cox RD, Allen EB (2008) Stability of exotic annual grasses following restoration efforts in southern California coastal sage scrub. Journal of Applied Ecology 45: 495-504. doi: 10.1111/j.1365-2664.2007.01437.x

Crall AW, Renz M, Panke BJ, Newman GJ, Chapin C, Graham J, Bargeron C (2012) Developing cost-effective early detection networks for regional invasions. Biological Invasions 14: 2461-2469. doi: 10.1007/s10530-012-0256-3

Crooks JA (2002) Characterizing ecosystem-level consequences of biological invasions: the role of ecosystem engineers. Oikos 97: 153-166. doi: 10.1034/j.1600-0706.2002.970201.x

Davison AW (1971) The ecology of Hordeum murinum L.: II. The ruderal habit. Journal of Ecology 59: 493-506. doi: 10.2307/2258327

DiTomaso JM, Kyser GB, Oneto SR, Wilson RG, Orloff SB, Anderson LW, Wright SD, Roncoroni JA, Miller TL, Prather TS, Ransom C, Beck KG, Duncan C, Wilso KA, Mann 
JJ (2013) Weed control in natural areas in the western United States. University of California, Weed Research and Information Center, Davis, California, USA.

Elkoca E, Kantar F, Zengin H (2005) Weed control in lentil (Lens culinaris) in eastern

Turkey. New Zealand Journal of Crop and Horticultural Science 33: 223-231. doi: 10.1080/01140671.2005.9514354

Foxcroft LC, Richardson DM, Wilson JRU (2008) Ornamental plants as invasive aliens: problems and solutions in Kruger National Park, South Africa. Environmental Management 41: 32-51. doi: 10.1007/s00267-007-9027-9

Foxcroft LC, Pyšek P, Richardson DM, Pergl J, Hulme PE (2013) The bottom line: impacts of alien plant invasions in protected areas. In: Foxcroft LC, Pyšek P, Richardson DM, Genovesi P (Eds) Plant invasions in protected areas: patterns, problems, and challenges. Springer, New York, 19-41. doi: 10.1007/978-94-007-7750-7_2

Gilbert B, Levine JM (2013) Plant invasions and extinction debts. Proceedings of the National Academy of Sciences 110: 1744-1749. doi: 10.1073/pnas.1212375110

Grossman JD, Rice KJ (2014) Contemporary evolution of an invasive grass in response to elevated atmospheric $\mathrm{CO}_{2}$ at a Mojave Desert FACE site. Ecology Letters 17: 710-716. doi: 10.1111/ele.12274

Halvorson WL, Guertin P (2003) Polypogon monspeliensis (L.) Desf. USGS Weeds in the West Project: status of introduced plants in southern Arizona parks. US Geological Survey, Southwest Biological Science Center, Tucson, Arizona, USA.

Hegeman EE, Dickson BG, Zachmann LJ (2014) Probabilistic models of fire occurrence across National Park Service units within the Mojave Desert Network, USA. Landscape Ecology 29: 1587-1600. doi: 10.1007/s10980-014-0078-z

Herrera J (1991) The reproductive biology of a riparian Mediterranean shrub, Nerium oleander L. (Apocynaceae). Botanical Journal of the Linnean Society 106: 147-172. doi: 10.1111/ j.1095-8339.1991.tb02289.x

Howard JL (2003) Sisymbrium altissimum. Fire Effects Information System. US Department of Agriculture, Forest Service, Rocky Mountain Research Station, Fire Sciences Laboratory. [online]

Hutchinson I, Colosi J, Lewin RA (1984) The biology of Canadian weeds. 63. Sonchus asper (L.) Hill and S. oleraceus. Canadian Journal of Plant Science 64: 731-744. doi: 10.4141/cjps84-100 Jennings WB (1997) Habitat use and food preferences of the desert tortoise, Gopherus agassizii, in the western Mojave Desert and impacts of off-road vehicles. In: Van Abbema J (Ed.) Proceedings: conservation, restoration, and management of tortoises and turtles - an international conference. New York Turtle and Tortoise Society and WCS Turtle Recovery Program, New York, 42-45.

Keeler-Wolf T (2007) Mojave Desert scrub vegetation. In: Barbour MG, Keeler-Wolf T, Schoenherr AA (Eds) Terrestrial vegetation of California. University of California Press, Berkeley, 609-656 . doi: 10.1525/california/9780520249554.003.0022

Keeley JE, Lubin D, Fotheringham CJ (2003) Fire and grazing impacts on plant diversity and alien plant invasions in the southern Sierra Nevada. Ecological Applications 13: 1355-1374. doi: $10.1890 / 02-5002$ 
Kemp PR, Brooks ML (1998) Exotic species of California deserts. Fremontia 26: 30-34.

Klinger R, Underwood EC, Moore PE (2006) The role of environmental gradients in nonnative plant invasion into burnt areas of Yosemite National Park, California. Diversity and Distributions 12: 139-156. doi: 10.1111/j.1366-9516.2005.00203.x

Lato LJ (2006) Soil survey of Clark County area, Nevada. US Department of Agriculture, Natural Resources Conservation Service. US Government Printing Office, Washington, DC.

Leger EA (2008) The adaptive value of remnant native plants in invaded communities: an example from the Great Basin. Ecological Applications 18: 1226-1235. doi: 10.1890/07-1598.1

Leger EA, Espeland EK (2010) Coevolution between native and invasive plant competitors: implications for invasive species management. Evolutionary Applications 3: 169-178. doi: 10.1111/j.1752-4571.2009.00105.x

Lovich JE, Bainbridge D (1999) Anthropogenic degradation of the southern California desert ecosystem and prospects for natural recovery and restoration. Environmental Management 24: 309-326. doi: 10.1007/s002679900235

Leys AR, Cullis BR, Plater B (1991) Effect of spraytopping applications of paraquat and glyphosate on the nutritive value and regeneration of vulpia (Vulpia bromoides (L.) S.F. Gray). Australian Journal of Agricultural Research 42: 1405-1415. doi: 10.1071/AR9911405

Lodge DM, Williams S, MacIsaac HJ, Hayes KR, Leung B, Reichard S, Mack RN, Moyle PB, Smith M, Andow DA, Carlton JT, McMichael A (2006) Biological invasions: recommendations for US policy and management. Ecological Applications 16: 2035-2054. doi: 10.1890/1051-0761(2006)016[2035:BIRFUP]2.0.CO;2

Marushia RG, Cadotte MW, Holt JS (2010) Phenology as a basis for management of exotic annual plants in desert invasions. Journal of Applied Ecology 47: 1290-1299. doi: 10.1111/j.1365-2664.2010.01881.x

Mau-Crimmins TM (2007) Effects of removing Cynodon dactylon from a recently abandoned agricultural field. Weed Research 47: 212-221. doi: 10.1111/j.1365-3180.2007.00556.x

McCune B, Mefford MJ (1999) PC-ORD: multivariate analysis of ecological data - User's guide. MjM Software Design, Gleneden Beach, Oregon.

Medica PA, Eckert SE (2007) Gopherus agassizii (desert tortoise) food/mechanical injury. Herpetological Review 38: 446-448.

Miller DM, Miller RJ, Nielson JE, Wilshire HG, Howard KA, Stone P (1991) Preliminary geologic map of the East Mojave National Scenic Area, California. Open-File Report 91-435. US Geological Survey, Reston, Virginia.

Miyanishi K, Cavers PB (1980) The biology of Canadian weeds. 40. Portulaca oleracea L. Canadian Journal of Plant Science 60: 953-963. doi: 10.4141/cjps80-139

National Park Service (2006) Management policies 2006. US Department of the Interior, National Park Service. US Government Printing Office, Washington, DC.

Natural Resources Conservation Service (2014) The PLANTS database. National Plant Data Center, Baton Rouge, Louisiana.

Oftedal OT, Hillard S, Morafka DJ (2002) Selective spring foraging by juvenile desert tortoises (Gopherus agassizii) in the Mojave Desert: evidence of an adaptive nutritional strategy. Chelonian Conservation and Biology 4: 341-352. 
Pauchard A, Alaback PB (2004) Influence of elevation, land use, and landscape context on patterns of alien plant invasions along roadsides in protected areas of south-central Chile. Conservation Biology 18: 238-248. doi: 10.1111/j.1523-1739.2004.00300.x

Pauchard A, Kueffer C, Dietz H, Daehler CC, Alexander J, Edwards PJ, Arévalo JR, Cavieres LA, Guisan A, Haider S, Jakobs G, McDougall K, Millar CI, Naylor BJ, Parks CG, Rew LJ, Seipel T (2009) Ain't no mountain high enough: plant invasions reaching new elevations. Frontiers in Ecology and Environment 7: 479-486. doi: 10.1890/080072

Pyšek P, Jarošík V, Kučera T (2002) Patterns of invasion in temperate nature reserves. Biological Conservation 104: 13-24. doi: 10.1016/S0006-3207(01)00150-1

Pyšek P, Jarošík V, Kučera T (2003) Inclusion of native and alien species in temperate nature reserves: an historical study from central Europe. Conservation Biology 17: 1414-1424. doi: 10.1046/j.1523-1739.2003.02248.x

Randall JM, Morse LE, Benton N, Hiebert R, Lu S, Killeffer T (2008) The Invasive Species Assessment Protocol: a tool for creating regional and national lists of invasive nonnative plants that negatively impact biodiversity. Invasive Plant Science and Management 1: 36-49. doi: 10.1614/IPSM-07-020.1

Rose M, Hermanutz L (2004) Are boreal ecosystems susceptible to alien plant invasion? Evidence from protected areas. Oecologia 139: 467-477. doi: 10.1007/s00442-004-1527-1

Schlaepfer MA, Sax DF, Olden JD (2011) The potential conservation value of non-native species. Conservation Biology 25: 428-437. doi: 10.1111/j.1523-1739.2010.01646.x

Schulz BK, Gray AN (2013) The new flora of northeastern USA: quantifying introduced plant species occupancy in forest ecosystems. Environmental Monitoring and Assessment 185: 3931-3957. doi: 10.1007/s10661-012-2841-4

Shafroth PB, Cleverly JR, Dudley TL, Taylor JP, Van Riper C, Weeks EP, Stuart JN (2005) Control of Tamarix in the western United States: implications for water salvage, wildlife use, and riparian restoration. Environmental Management 35: 231-246. doi: 10.1007/ s00267-004-0099-5

Steers RJ, Allen EB (2010) Post-fire control of invasive plants promotes native recovery in a burned desert shrubland. Restoration Ecology 18: 334-343. doi: 10.1111/j.1526100X.2009.00622.x

Sullivan J (1992) Medicago sativa. In Fire Effects Information System. US Department of Agriculture, Forest Service, Rocky Mountain Research Station, Fire Sciences Laboratory. [online]

Theoharides KA, Dukes JS (2007) Plant invasion across space and time: factors affecting nonindigenous species during four stages of invasion. New Phytologist 176: 256-273. doi: 10.1111/j.1469-8137.2007.02207.x

Thomas KA, Keeler-Wolf T, Franklin J, Stine P (2004) Mojave Desert ecosystem program: central Mojave vegetation mapping database. US Geological Survey, Western Regional Science Center and Southwest Biological Science Center, Flagstaff, Arizona.

Turkington RA, Cavers PB, Rempel E (1978) The biology of Canadian weeds. 29. Melilotus alba Desr. And M. officinalis (L.) Lam. Canadian Journal of Plant Science 58: 523-537. doi: $10.4141 /$ cjps78-078 
Van Linn PF, Nussear KE, Esque TC, DeFalco LA, Inman RD, Abella SR (2013) Estimating wildfire risk on a Mojave Desert landscape using remote sensing and field sampling. International Journal of Wildland Fire 22: 770-779. doi: 10.1071/WF12158

Vogel J, Hughson DL (2009) Historical patterns of road networks in Mojave National Preserve. In: Webb RH, Fenstermaker LF, Heaton JS, Hughson DL, McDonald EV, Miller DM (Eds) The Mojave Desert: ecosystem processes and sustainability. University of Nevada Press, Reno, Nevada, 196-210.

Walker LR, Barnes PL, Powell EA (2006) Tamarix aphylla: a newly invasive tree in southern Nevada. Western North American Naturalist 66: 191-201. doi: 10.3398/1527-0904(2006)66[191:TAANIT]2.0.CO;2

Wallace CSA, Thomas KA (2008) An annual plant growth proxy in the Mojave Desert using MODIS-EVI data. Sensors 8: 7792-7808. doi: 10.3390/s8127792

Warner PJ, Bossard CC, Brooks ML, DiTomaso JM, Hall JA, Howald AM, Johnson DW, Randall JM, Roye CL, Ryan MM, Stanton AE (2003) Criteria for categorizing invasive nonnative plants that threaten wildlands. California Exotic Pest Plant Council and Southwest Vegetation Management Association, Berkeley, California.

Weaver SE, Lechowicz MJ (1998) The biology of Canadian weeds. 56. Xanthium strumarium L. Canadian Journal of Plant Science 63: 211-225. doi: 10.4141/cjps83-021

Weiss JER (1996) Control of horehound, Marrubium vulgare L., in Wyperfeld National Park, Victoria. In: Shepherd RCH (Ed.) $11^{\text {th }}$ Australian weeds conference proceedings: where in the world is weed science going? Weed Science Society of Victoria, Batman, Victoria, 417-419. Whipple JJ (2001) Annotated checklist of exotic vascular plants in Yellowstone National Park. Western North American Naturalist 61: 336-346.

Widderick M, Walker S, Sindel B (2004) Better management of Sonchus oleraceus L. (common sowthistle) based on the weed's ecology. In: Sindel BM, Johnson SB (Eds) $14^{\text {th }}$ Australian weeds conference proceedings: weed management - balancing people, planet, and profit. Weed Society of New South Wales, Wahroonga, 535-537. 